\title{
Resistance of Human Tumor Cells In Vitro to Oxidative Cytolysis
}

Jill O'Donnell-Tormey, Carol J. DeBoer, and Carl F. Nathan

Laboratory of Cellular Physiology and Immunology, The Rockefeller University, New York, New York 10021

\begin{abstract}
Nine human cell types, six of them malignant, displayed a marked resistance to lysis by hydrogen peroxide $\left(\mathrm{LD}_{50}, 2-20\right.$ $\mathrm{mM})$. Of the reactive oxygen intermediates generated extracellularly, only $\mathrm{H}_{2} \mathrm{O}_{2}$ lysed all the cell types. $\mathrm{OH}^{\circ}$ was lytic to one of four, $\mathrm{OI}^{-}$to one of one, and $\mathrm{O}_{2}^{-}$to none of four cell types tested. Resistance to oxidative lysis did not correlate with specific activity of catalase, glutathione (GSH) peroxidase, other peroxidases, or glutathione disulfide reductase, or with specific content of GSH. Resistance to $\mathrm{H}_{2} \mathrm{O}_{2}$ seemed to occur via mechanisms distinct from those responsible for cellular consumption of $\mathrm{H}_{2} \mathrm{O}_{2}$. Consumption was inhibitable by azide and was probably due to catalase in each cell type. In contrast, resistance to oxidative lysis occurred via distinct routes in different cells. One cell type used the GSH redox cycle as the primary defense against $\mathrm{H}_{2} \mathrm{O}_{2}$, like murine tumors previously studied. Other cells seemed to utilize catalase as the major defense against $\mathrm{H}_{2} \mathrm{O}_{2}$. Nonetheless, with both catalase and the GSH redox cycle inhibited, all the human cells tested exhibited an inherent resistance to oxidative lysis, that is, resistance independent of detectable degradation of $\mathrm{H}_{2} \mathrm{O}_{2}$.
\end{abstract}

\section{Introduction}

Hydrogen peroxide, a secretory product of activated macrophages and granulocytes, lyses murine tumor cells under some experimental conditions (1). A major defense of murine tumors against lysis by $\mathrm{H}_{2} \mathrm{O}_{2}$ is the glutathione $(\mathrm{GSH})^{1}$ redox cycle (2-4). Thus, threefold to 10 -fold smaller fluxes of $\mathrm{H}_{2} \mathrm{O}_{2}$ were required to lyse tumor cells after inhibition of their GSH peroxidase by deprivation of selenium (2), inactivation of GSSG reductase with 1,3-bis(2-chloroethyl)-1-nitrosourea (BCNU) (2), blockade of $\gamma$-glutamylcysteine synthetase with

Address reprint requests to Dr. O'Donnell-Tormey.

Received for publication 8 August 1984 and in revised form 22 March 1985.

1. Abbreviations used in this paper: AT, 3-amino-1,2,4-triazole; BCNU, 1,3-bis(2-chlorethyl)-1-nitrosourea; BSO, buthionine sulfoximine; FBS, heat-inactivated fetal bovine serum; GR, glutathione reductase; GSH, glutathione; KRPG, Krebs-Ringer phosphate buffer containing 7.2 $\mathrm{mM}$ phosphate and $5.5 \mathrm{mM}$ glucose; $\mathrm{LD}_{50}, 50 \%$ specific lysis; $\mathrm{M}-5 \%$ HS, $\alpha$-modified Eagle's minimal essential medium with $5 \%$ heatinactivated horse serum; M-S, $\alpha$-modified Eagle's minimal essential medium with $0.1 \mathrm{mM}$ nonessential amino acids, $15 \%$ FBS and 100 $\mathrm{U} / \mathrm{ml}$ penicillin and $100 \mu \mathrm{g} / \mathrm{ml}$ streptomycin; MEM, minimal essential medium; $\mathrm{P} / \mathrm{S}_{2}, 100 \mathrm{U} / \mathrm{ml}$ penicillin, $100 \mu \mathrm{g} / \mathrm{ml}$ streptomycin; R-S, RPMI 1640 medium supplemented with $1 \mathrm{mM}$ pyruvate, $300 \mu \mathrm{g} / \mathrm{ml}$ glutamine, $0.1 \mathrm{mM}$ nonessential amino acids, $100 \mathrm{U} / \mathrm{ml}$ penicillin, $100 \mu \mathrm{g} / \mathrm{ml}$ streptomycin, and heat-inactivated FBS.

J. Clin. Invest.

(c) The American Society for Clinical Investigation, Inc.

0021-9738/85/07/0080/07 \$1.00

Volume 76, July 1985, 80-86 buthionine sulfoximine (BSO) (3), or acute GSH depletion with chlorodinitrobenzene (3) or sulfhydryl-reactive natural products including sesquiterpene lactones (4). In contrast, murine tumor cell catalase seemed to play a secondary role in defense against oxidative lysis $(2,3)$.

In this report, we have attempted to define which reactive oxygen intermediates are rapidly lytic for various human cells (mostly tumors) and at what concentrations, to correlate relative resistance with the activity of the GSH redox cycle and catalase, and to analyze the role of these antioxidant enzymes in the consumption of $\mathrm{H}_{2} \mathrm{O}_{2}$ by intact cells and in the resistance of the cells to lysis by $\mathrm{H}_{2} \mathrm{O}_{2}$. The results indicate that the specific activities of catalase and the GSH redox cycle components in cell lysates predict neither the $\mathrm{H}_{2} \mathrm{O}_{2}$ consumption nor the resistance of the intact cell. Moreover, $\mathrm{H}_{2} \mathrm{O}_{2}$ consumption and resistance can occur by apparently different mechanisms. These findings may be relevant for pathophysiologic concepts and therapeutic designs based on oxidant injury of human cells.

\section{Methods}

Cells. Three breast adenocarcinoma cell lines were used. SK-BR-1-III, derived from a pleural effusion (5), was grown as a suspension in RPMI 1640 medium (KC Biologicals, Lenexa, KS) supplemented with $1 \mathrm{mM}$ pyruvate, $300 \mu \mathrm{g} / \mathrm{ml}$ glutamine, $0.1 \mathrm{mM}$ nonessential amino acids, $100 \mathrm{U} / \mathrm{ml}$ penicillin, $100 \mu \mathrm{g} / \mathrm{ml}$ streptomycin $\left(\mathrm{P} / \mathrm{S}_{2}\right)$ (Gibco Laboratories, Grand Island, NY), and $20 \%$ heat-inactivated fetal bovine serum $\left(\mathrm{FBS}_{20}\right)$ (HyClone Laboratories, Logan, UT). This medium is designated R-S. SK-BR-2-III, explanted from ascites, was grown in suspension in R-S. CAMA-I, from a pleural effusion, was grown as a monolayer in $\alpha$-modified Eagle's minimum essential medium (KC Biologicals) with $0.1 \mathrm{mM}$ nonessential amino acids, $15 \%$ heat-inactivated fetal bovine serum (FBS), and $\mathbf{P} / \mathbf{S}_{2}$. This medium is designated $\mathrm{M}-\mathrm{S}$. SK-OV-3, an ovarian adenocarcinoma cell line derived from ascites (5-7), was grown as a monolayer in R-S. The above lines were obtained from Dr. J. Fogh, Sloan-Kettering Institute, Rye, NY. B0467, an Epstein-Barr virus-induced B cell line grown in suspension in R-S, was obtained from Dr. N. Chiorazzi, The Rockefeller University, New York, NY. HSB, a T cell line from a patient with acute lymphocytic leukemia, was obtained from the Human Genetic Mutant Cell Repository, Institute for Medical Research, Camden, NJ, and was grown in suspension in R-S. CCD-21SK, a human skin fibroblast line, was obtained from American Type Culture Collection, Bethesda, MD, and was grown as an adherent monolayer in M-S. All cell lines were periodically checked for mycoplasma and found to be negative by fluorescent bisbenzimide staining (Hoechst 33342; Aldrich Chem. Co., Milwaukee, WI). Normal human lymphocytes were isolated from buffy coats purchased from the New York Blood Center. Mononuclear leukocytes were obtained as described (8) with collection of the cells that were nonadherent to glass after 2-4 h incubation in RPMI 1640 medium containing $25 \%$ human serum. The nonadherent mononuclear cells, which were $82 \%$ positive by direct immunofluorescence with monoclonal anti-Leu-4 antibody (Becton-Dickinson \& Co., Oxnard, $\mathrm{CA}$ ), were incubated in R-S for 17-30 h before use. Normal human erythrocytes were isolated from heparinized $(30 \mathrm{U} / \mathrm{ml})$ venous blood and washed by centrifugation in RPMI and used immediately. Each experiment with normal human erythrocytes and/or lymphocytes used 
a different donor as the cell source. Mouse mastocytoma (P815) and lymphoma cells (L1210, P388, TLX9) were as described $(2,9)$.

Cytolysis assay. To determine susceptibility to lysis by $\mathrm{H}_{2} \mathrm{O}_{2}$, nonadherent cells, usually numbering $2-5 \times 10^{6}$, were suspended in 2 $\mathrm{ml} \alpha$-modified minimal essential medium (MEM)-5\% heat-inactivated horse serum (HyClone Laboratories) (M-5\% HS) with $200 \mu \mathrm{Ci}$ of $\mathrm{Na}_{2}{ }^{51} \mathrm{CrO}_{4}$ (New England Nuclear, Boston, MA), incubated at $37^{\circ} \mathrm{C}$ in $5 \% \mathrm{CO}_{2} / 95 \%$ air for $60 \mathrm{~min}$, and washed four times by centrifugation in M-5\% HS. Cell concentration and viability were determined by counting trypan blue-excluding cells in a hemocytometer. $4 \times 10^{4}$ ${ }^{51} \mathrm{Cr}$-labeled cells in $0.2 \mathrm{ml} \mathrm{M}-5 \%$ HS were added to round-bottomed microtest plate wells (Linbro Division, Flow Laboratories, McLean, VA) containing graded amounts of $\mathrm{H}_{2} \mathrm{O}_{2}$ (Superoxol; Fisher Chemical Co., Fairlawn, NJ) or glucose oxidase (Sigma Chemical Co., St. Louis, $\mathrm{MO}$ ), diluted in $0.9 \% \mathrm{NaCl}$. When glucose oxidase was used, the glucose concentration was raised to $40 \mathrm{mM} . \mathrm{H}_{2} \mathrm{O}_{2}$ generated by glucose oxidase was measured using the $\mathrm{O}_{2}$ monitor as described below for $\mathrm{H}_{2} \mathrm{O}_{2}$ consumption. Plates were incubated at $37^{\circ} \mathrm{C}$ in $5 \% \mathrm{CO}_{2} / 95 \%$ air for $3 \mathrm{~h}$. For murine tumor cells, non- $\alpha$-modified MEM was used as before (9). After centrifugation at $550 \mathrm{~g}$ for $5 \mathrm{~min}, 0.1 \mathrm{ml}$ supernate was removed for gamma counting. Results were similar when the assay time was extended to $4.5,6$, or $16 \mathrm{~h}$, or when $5 \%$ horse serum was replaced with $5 \%$ human serum or $0.005 \%$ gelatin (Fisher Chemical Co.). For adherent cells, $2 \times 10^{5}$ cells were plated on $13-\mathrm{mm}$ diam glass coverslips in 24-well Costar plates (Data Packaging, Inc., Cambridge, MA), labeled by the addition of $1 \mathrm{ml} \mathrm{M}-5 \%$ HS containing 2 $\mu \mathrm{Ci} \mathrm{Na}_{2}{ }^{51} \mathrm{CrO}_{4}$ for $60 \mathrm{~min}$ at $37^{\circ} \mathrm{C}$ in $5 \% \mathrm{CO}_{2} / 95 \%$ air, and washed four times in M-5\% HS. The cells were then incubated in $1 \mathrm{ml} \mathrm{M}-5 \%$ HS with or without $\mathrm{H}_{2} \mathrm{O}_{2}$ for $3 \mathrm{~h}$, centrifuged as above, and $0.5 \mathrm{ml}$ supernate was removed as sample. The residual supernate was pooled with the $0.5 \mathrm{~N} \mathrm{NaOH}$ lysate of the remaining cells and both the sample and residual were used for gamma counting. The concentration of $\mathrm{H}_{2} \mathrm{O}_{2}$ causing $50 \%$ specific lysis $\left(\mathrm{LD}_{50}\right)$ was calculated by interpolation as previously described (9). Determination of cell susceptibility to lysis by superoxide and hydroxyl radicals was performed as above with modifications to reduce the scavenging effect of serum on these oxygen intermediates. ${ }^{51} \mathrm{Cr}$-labeled cells were placed in serum-coated borosilicate glass tubes $(12 \times 75 \mathrm{~mm})$ in Krebs-Ringer phosphate buffer containing $7.2 \mathrm{mM}$ phosphate and $5.5 \mathrm{mM}$ glucose (KRPG) (8) in the presence of graded amounts of $\mathrm{KO}_{2}$ (Sigma Chemical Co.), or $\mathrm{H}_{2} \mathrm{O}_{2}$ together with an equimolar amount of $\mathrm{FeSO}_{4}$ (chelated by a threefold molar excess of EDTA) (Sigma Chemical Co.) for $30 \mathrm{~min}$ at $37^{\circ} \mathrm{C}$ in air. M$5 \% \mathrm{HS}$ was then added and the tubes were incubated in $5 \% \mathrm{CO}_{2} / 95 \%$ air for an additional $2 \mathrm{~h}$ to allow for completion of the ${ }^{51} \mathrm{Cr}$ release. Adherent cells were treated similarly except that cell-bearing coverslips were placed in serum-coated 24-well plates. Effects of $\mathrm{OI}^{-}$were determined by a 3-h incubation in microtest plates of $4 \times 10^{4}$ cells in $200 \mu$ l KRPG containing $\mathbf{0 . 0 0 5 \%}$ gelatin together with lactoperoxidase (Sigma Chemical Co.), iodide, and $\mathrm{H}_{2} \mathrm{O}_{2}$ as indicated. Lysis as estimated by the specific release of ${ }^{51} \mathrm{Cr}$ was closely comparable to lysis estimated from hemocytometer counts of cells excluding $0.2 \%$ trypan blue.

Biochemical assays. Total cell glutathione (GSH plus GSSG) was measured according to Tietze $(10)$ in the $2.5 \%$ sulfosalicylic acidsoluble fraction of $0.1 \%$ Triton X-100 (Sigma Chemical Co.) lysates. GSSG reductase (GR) was assayed according to Roos et al. (11), and GSH peroxidase according to Paglia and Valentine (12). Catalase was measured by two methods. The colorimetric assay of Baudhuin et al. (13) detects the interference by cell lysates with the oxidation of titanium sulfate by exogenous $\mathrm{H}_{2} \mathrm{O}_{2}$. For more sensitive determinations, polarimetry was employed with an oxygen electrode (Model 53; Yellow Springs Instrument $\mathrm{Co}$., Yellow Springs, $\mathrm{OH}$ ) coupled to a magnetically stirred, water-jacketed vessel. The system was calibrated at $37^{\circ} \mathrm{C}$ using air-saturated phosphate-buffered saline $(9.53 \mathrm{mM}$ phosphate, $0.15 \mathrm{M}$ sodium, $0.14 \mathrm{M}$ chloride, $4.15 \mathrm{mM}$ potassium, $\mathrm{pH}$ 7.4) (PBS). Then $2.95 \mathrm{ml}$ PBS containing $5 \mathrm{mM} \mathrm{H}_{2} \mathrm{O}_{2}$ was purged with $\mathrm{N}_{2}$ until $<5 \%$ of the base-line $\mathrm{O}_{2}$ concentration was detected. $50 \mu \mathrm{l}$ of $0.2 \%$ Triton $\mathrm{X}-100$ cell lysate $\left(4 \times 10^{7}\right.$ cells $\left./ \mathrm{ml}\right)$ was added and catalase activity was determined from the nanomoles of $\mathrm{O}_{2}$ generated per minute per cell number or cell protein. Cellular peroxidases were measured with three different cosubstrates (Sigma Chemical Co.): guaiacol by the method of Maehly and Chance (14), NADH by a modified method of Avigad (15), and ascorbate as described (16). Protein was determined by the method of Lowry et al. (17) with bovine serum albumin as the standard. $\mathrm{H}_{2} \mathrm{O}_{2}$ was measured by the horseradish peroxidase-catalyzed oxidation of fluorescent scopoletin (8), $\mathrm{O}_{2}^{-}$by the superoxide dismutaseinhibitable reduction of ferricytochrome $\mathrm{c}(8)$, and $\mathrm{OH}^{*}$ by the production of formaldehyde from dimethylsulfoxide (18).

$\mathrm{H}_{2} \mathrm{O}_{2}$ consumption. Cells were incubated at $37^{\circ} \mathrm{C}$ in $5 \% \mathrm{CO}_{2} / 95 \%$ air at $1 \times 10^{6}$ cells $/ \mathrm{ml} \mathrm{M-5 \%} \mathrm{HS} \mathrm{for} \mathrm{nonadherent} \mathrm{cells} \mathrm{and} \sim 5 \times 10^{5}$ cells per coverslip in $1 \mathrm{ml} \mathrm{M}-5 \% \mathrm{HS}$ for adherent cells. At time 0,5 $\mathrm{mM} \mathrm{H} \mathrm{H}_{2} \mathrm{O}_{2}$ was added. At $0,30,60$, and $180 \mathrm{~min}$, the $\mathrm{H}_{2} \mathrm{O}_{2}$ concentration was determined on aliquots by a modification of the method of Schroy and Biaglow (19). The oxygen electrode system described above was calibrated with air-saturated PBS. $2.8 \mathrm{ml}$ PBS containing $200 \mathrm{U} / \mathrm{ml}$ bovine liver catalase (Sigma Chemical Co.) were purged with $\mathrm{N}_{2}$. A $200-\mu 1$ aliquot of the reaction medium was added with a Hamilton syringe and the generation of $\mathrm{O}_{2}$ was followed to completion. $\mathrm{H}_{2} \mathrm{O}_{2}$ was calculated as twice the generated $\mathrm{O}_{2}$.

Enzyme inhibitors. Sodium azide (Fisher Chemical Co.) was dissolved in $0.9 \% \mathrm{NaCl}$ and added to cells at $0.5 \mathrm{mM}$ immediately before assay. 3-amino-1,2,4-triazole (AT; Sigma Chemical Co.) was dissolved in $\mathrm{M}-5 \% \mathrm{HS}$ and added to cells at $50 \mathrm{mM}$ for $60 \mathrm{~min}$ during ${ }^{51} \mathrm{Cr}$ labeling as well as during assays. BSO (Chemical Dynamics Corp., S. Plainfield, $\mathrm{NJ}$ ) was dissolved in $\mathrm{H}_{2} \mathrm{O}$ at $20 \mathrm{mM}$ and cells were exposed to $0.2 \mathrm{mM}$ BSO for $17 \mathrm{~h}$ before ${ }^{51} \mathrm{Cr}$-labeling and throughout the assays. BCNU (Bristol Laboratories, Syracuse, NY) was dissolved in absolute ethanol at $100 \mathrm{mg} / \mathrm{ml}$, diluted to $1 \mathrm{mg} / \mathrm{ml}$ in $\mathrm{MEM}$, and added to cells at $100 \mu \mathrm{g} / \mathrm{ml}$ for the last $10 \mathrm{~min}$ of ${ }^{51} \mathrm{Cr}$-labeling.

\section{Results}

Identification of cytolytic oxygen reduction products. To determine which extracellularly generated oxygen reduction products rapidly lyse human cells, and therefore which enzymes might be involved in defense against oxidative cytolysis, we compared the susceptibility of fibroblasts, SK-BR-1-III, SK-BR-2-III, erythrocytes, and CAMA-I to $\mathrm{H}_{2} \mathrm{O}_{2}, \mathrm{O}_{2}^{-}$, and $\mathrm{OH}^{\circ}$. Lysis first was attempted with the $\mathrm{H}_{2} \mathrm{O}_{2}$ generating system of glucose oxidase and glucose, which lysed most murine tumors tested (1). However, fluxes of $\mathrm{H}_{2} \mathrm{O}_{2}$ (nanomoles per minute per 0.2 $\mathrm{ml})$ up to 3 for fibroblasts, 14 for SK-BR-1-III, 15 for SK-BR2-III, 21 for erythrocytes, and 105 for CAMA-I failed to produce substantial lysis (not shown). Consistent with this, there was no significant lysis of SK-BR-2-III or fibroblasts by phorbol myristate acetate-stimulated human granulocytes or monocytes at a 10-fold or 20-fold excess over target cells during $6 \mathrm{~h}$ of co-incubation (not shown). We therefore tested these cells' susceptibility to preformed $\mathrm{H}_{2} \mathrm{O}_{2}$. As shown in Fig. 1 for SK-BR-2-III, $\mathrm{H}_{2} \mathrm{O}_{2}$ was lytic in a dose-dependent, catalaseinhibitable manner. $50 \%$ lysis by $3 \mathrm{~h}$ required $1.2 \mathrm{mM} \mathrm{H}_{2} \mathrm{O}_{2}$. Results were similar with the other four cell types.

We next attempted to lyse these cells with the $\mathrm{O}_{2}$-generating system of xanthine oxidase and acetaldehyde. Using each agent at the maximal nontoxic concentration, only $\mu \mathrm{M}$ concentrations of $\mathrm{O}_{2}^{-}$were detected. As these concentrations were not cytolytic, we employed preformed $\mathrm{O}_{2}^{-}\left(\right.$as $\left.\mathrm{KO}_{2}\right)$. Fig. 1 shows that lysis of SK-BR-2-III by $<10 \mathrm{mM} \mathrm{O}_{2}^{-}$was inhibitable by catalase and thus presumably due to dismutation of $\mathrm{O}_{2}^{-}$to $\mathrm{H}_{2} \mathrm{O}_{2}$. At $10 \mathrm{mM} \mathrm{O}_{2}^{-}$, catalase was no longer inhibitory, but the same extent of cytolysis was seen by bringing the $\mathrm{pH}$ of the medium to 10.5 , the $\mathrm{pH}$ attained with $10 \mathrm{mM} \mathrm{O}_{2}^{-}$, as anticipated from the reaction: $2 \mathrm{O}_{2}^{-}+2 \mathrm{H}^{+} \rightarrow \mathrm{H}_{2} \mathrm{O}_{2}+\mathrm{O}_{2}$ (20). Results were similar for CAMA-I, fibroblasts, and erythrocytes (not shown). 


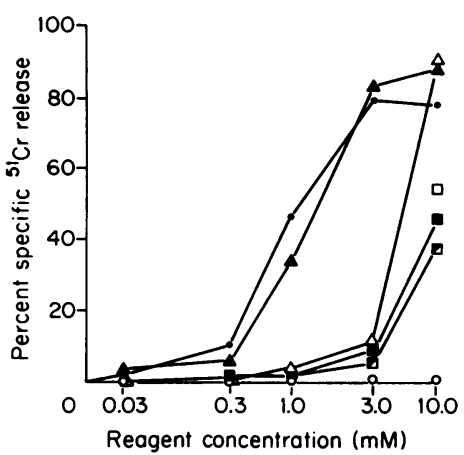

Figure 1. Effect of oxygen intermediates on SK-BR-2 III viability. $2 \times 10^{551} \mathrm{Cr}$ labeled SK-BR-2-III cells in KRPG were incubated in a $37^{\circ} \mathrm{C}_{2} \mathrm{O}$ bath in serumcoated borosilicate glass tubes in the presence of the indicated concentrations of $\mathrm{H}_{2} \mathrm{O}_{2}, \mathrm{KO}_{2}$, or $\mathrm{H}_{2} \mathrm{O}_{2}$ with EDTA-chelated $\mathrm{FeSO}_{4}$, all in the presence or absence of $2,000 \mathrm{U} / \mathrm{ml}$ catalase for $30 \mathrm{~min}$. M-5\% HS was then added to all tubes and they were transferred to a $37^{\circ} \mathrm{C}$ incubator with $5 \% \mathrm{CO}_{2} / 95 \%$ air for an additional $2 \mathrm{~h}$. Percent specific ${ }^{51} \mathrm{Cr}$ release was then measured. (๑), $\mathrm{H}_{2} \mathrm{O}_{2} ;(\bullet), \mathrm{KO}_{2} ;(\bullet), \mathrm{H}_{2} \mathrm{O}_{2}+$ EDTAchelated $\mathrm{FeSO}_{4} ;(\square)$, EDTA-chelated $\mathrm{FeSO}_{4} ;(0), \mathrm{H}_{2} \mathrm{O}_{2}+$ catalase; $(\triangle), \mathrm{KO}_{2}+$ catalase; ( $(\mathrm{c}), \mathrm{H}_{2} \mathrm{O}_{2}+$ EDTA-chelated $\mathrm{FeSO}_{4}+$ catalase Values on the abscissa represent the concentration of added oxygen intermediate and/or $\mathrm{FeSO}_{4}$. EDTA was present in threefold molar excess over $\mathrm{FeSO}_{4}$. Points are means of triplicates in two or more experiments.

To generate $\mathrm{OH}^{*}$, we added EDTA-chelated $\mathrm{FeSO}_{4}$ to $\mathrm{H}_{2} \mathrm{O}_{2}$. This resulted in rapid loss of $\mathrm{H}_{2} \mathrm{O}_{2}$ and generation of formaldehyde from added dimethylsulfoxide (18), indicating the production of at least micromolar concentrations of $\mathrm{OH}^{\circ}$. However, as shown in Fig. 1 for SK-BR-2-III, only marginal cell lysis was attained with these reagents, and this could be reproduced with EDTA-chelated $\mathrm{FeSO}_{4}$ alone. Results were similar with CAMA-I and erythrocytes. The sensitivity of fibroblasts to $\mathrm{H}_{2} \mathrm{O}_{2}$, however, was enhanced by $\mathrm{EDTA}-\mathrm{FeSO}_{4}$ and this enhancement was abolished by catalase, suggesting that this cell type was susceptible to $\mathrm{OH}^{\circ}$ derived from $\mathrm{H}_{2} \mathrm{O}_{2}$.

As first shown for bacteria by Klebanoff (21) and for mammalian cells by Edelson and Cohn (22), the hypohalite generated by $\mathrm{H}_{2} \mathrm{O}_{2}$, peroxidase, and halide is extremely cytotoxic. Table I illustrates the finding that $\mathrm{H}_{2} \mathrm{O}_{2}$-dependent lysis of SK-BR-2-III was augmented $\sim 100$-fold by lactoperoxidase and iodide. Catalase prevented lysis. Azide, which was expected to inhibit lactoperoxidase, nonetheless augmented lysis twoto threefold. The tumor cells seemed to be using an azidesensitive pathway for protection against $\mathrm{H}_{2} \mathrm{O}_{2}$.

The foregoing results suggested that the more reduced forms of $\mathrm{O}_{2}$, primarily $\mathrm{H}_{2} \mathrm{O}_{2}$ and $\mathrm{IO}^{-}$, and in some cases $\mathrm{OH}^{*}$,

Table I. Potentiation of $\mathrm{H}_{2} \mathrm{O}_{2}$ Lysis of SK-BR-2-III by Peroxidase and Iodide

\begin{tabular}{lc}
\hline Treatment & $\mathbf{L D}_{\text {so }}$ \\
\hline & $m M$ \\
$\mathrm{H}_{2} \mathrm{O}_{2}$ & 5.35 \\
$\mathrm{H}_{2} \mathrm{O}_{2}+\mathrm{LPO} / \mathrm{KI}$ & 0.05 \\
$\mathrm{H}_{2} \mathrm{O}_{2}+\mathrm{LPO} / \mathrm{KI}+$ catalase & $>30$ \\
$\mathrm{H}_{2} \mathrm{O}_{2}+\mathrm{LPO} / \mathrm{KI}+$ azide & 2.05 \\
$\mathrm{H}_{2} \mathrm{O}_{2}+$ azide & 2.25
\end{tabular}

$4 \times 10^{4}{ }^{51} \mathrm{Cr}$-labeled SK-BR-2-III cells in $200 \mu \mathrm{l} \mathrm{KRPG} \mathrm{containing}$ $0.005 \%$ gelatin were incubated for $3 \mathrm{~h}$ at $37^{\circ} \mathrm{C}$ in air in the presence of $\mathrm{H}_{2} \mathrm{O}_{2}$ (ranging from 0.03 to $30 \mathrm{mM}$ ) with and without $1,000 \mathrm{U} / \mathrm{ml}$ lactoperoxidase, $0.1 \mathrm{mM} \mathrm{KI}, 2,000 \mathrm{U} / \mathrm{ml}$ catalase, and $1.5 \mathrm{mM}$ azide. Specific ${ }^{51} \mathrm{Cr}$ release was measured and concentrations of $\mathrm{H}_{2} \mathrm{O}_{2}$ resulting in $50 \%$ lysis of cells $\left(\mathrm{LD}_{50}\right)$ were calculated by interpolation. were lytic to human cells, while the less reduced $\mathrm{O}_{2}^{-}$was not. As there is no known enzymatic defense against $\mathrm{IO}^{-}$or $\mathrm{OH}^{+}$, we next focused on the cells' enzymatic defenses against $\mathrm{H}_{2} \mathrm{O}_{2}$.

Quantification of susceptibility of human cells to $\mathrm{H}_{2} \mathrm{O}_{2}$ and relation to levels of catalase, GSH redox cycle components, and other peroxidases. Study of human cell susceptibility to and defense against $\mathrm{H}_{2} \mathrm{O}_{2}$ was undertaken with the following cell types: three breast adenocarcinomas, of which two (SKBR-2-III and SK-BR-1-III) were nonadherent and one (CAMAI) was adherent, an adherent ovarian adenocarcinoma (SKOV-3), a nonadherent B cell line (B0467), a nonadherent leukemic $T$ cell line (HSB), an adherent, contact-inhibited diploid skin fibroblast line (CCD-21-SK), erythrocytes, and peripheral blood lymphocytes. All nine of these human cell types exhibited far greater resistance to lysis by $\mathrm{H}_{2} \mathrm{O}_{2}$ than previously studied murine cells, with $\mathrm{LD}_{50} \mathrm{~s}$ ranging from 2 to $20 \mathrm{mM}$ (Table II). In contrast to a number of earlier reports on oxidative lysis of human cells, these experiments were conducted in media of physiologic tonicity, $\mathrm{pH}$, and glucose concentration.

Several potential scavengers of $\mathrm{H}_{2} \mathrm{O}_{2}$ were measured in each cell type (Table II). Although human tumors have been said to lack catalase $(23,24)$, we found catalase activities varying over a 38-fold range for tumors and over a 3,000-fold range for nonmalignant cells. GR activities varied 250 -fold and GPO activities varied 65 -fold. No correlation between susceptibility to $\mathrm{H}_{2} \mathrm{O}_{2}$ and the activity of any of these enzymes was observed. GSH content was similar among all the cell types. No peroxidases were detected that utilized guaiacol, $\mathrm{NADH}$, or ascorbate as substrates.

Effect of inhibition of antioxidant defenses on lysis by $\mathrm{H}_{2} \mathrm{O}_{2}$. To understand better the role that these $\mathrm{H}_{2} \mathrm{O}_{2}$ scavengers might play in protecting cells from oxidative stress, we measured sensitivity of the cells to lysis by $\mathrm{H}_{2} \mathrm{O}_{2}$ in the presence of inhibitors or depletors of the antioxidants. Thus, the GSH redox cycle was interrupted by $75-100 \%$ inhibition of GR with BCNU, and by inhibition of GSH synthesis with BSO, resulting in 70-98\% depletion of GSH. To inhibit cellular catalase, we first used AT. By the colorimetric method of Baudhuin et al. (13), AT apparently afforded $100 \%$ inhibition of catalase. However, a fivefold more sensitive assay of catalase based on the polarigraphic determination of the generation of $\mathrm{O}_{2}$ from $\mathrm{H}_{2} \mathrm{O}_{2}$ indicated that inhibition by $\mathrm{AT}$ was variable (85-100\%), even in the presence of exogenous $\mathrm{H}_{2} \mathrm{O}_{2}$ (25). In contrast, $0.5 \mathrm{mM}$ sodium azide resulted in $100 \pm 5 \%$ (mean \pm SEM, 12 experiments) inhibition of human cell catalase, as determined polarigraphically.

The effect of the above agents on the $\mathrm{LD}_{50}$ of $\mathrm{H}_{2} \mathrm{O}_{2}$ for each of nine human cell types is shown in Table III. BCNU and $\mathrm{BSO}$ reduced the $\mathrm{LD}_{50}$ of $\mathrm{H}_{2} \mathrm{O}_{2}$ for fibroblasts by 10- to 20-fold. In contrast, the GSH redox cycle in two other nonmalignant cell types (lymphocytes and erythrocytes) and in all the tumors studied except SK-BR-1-III, appeared unable to substantially protect cells from lysis by $\mathrm{H}_{2} \mathrm{O}_{2}$. In contrast to the other cell types studied, in SK-BR-1-III BSO and BCNU treatments had different effects on $\mathrm{H}_{2} \mathrm{O}_{2}$ sensitivity. It is possible that other effects of BCNU besides inhibition of GR may be more prominent in this cell type. Inhibition of catalase with azide reduced $\mathrm{LD}_{50}$ s by $66-70 \%$ for lymphocytes, erythrocytes, and all the tumors except B0467 and HSB. Similar results were often seen with AT implicating an effect on catalase rather than on mitochondrial respiration. B0467 and 
Table II. Antioxidant Defenses in Human Cells

\begin{tabular}{lcccrc}
\hline Cell type & LD & Catalase & GSH & GPO & GR \\
& $m M$ & & & & \\
Erythrocytes & $1.7 \pm 0.1^{*}$ & $2,300 \pm 942$ & $9.5 \pm 2.3$ & $16.1 \pm 5.2$ & $30.5 \pm 3.2$ \\
SK-BR-2-III & $3.3 \pm 0.7$ & $22.6 \pm 2.5$ & $30.0 \pm 0.8$ & $0.0 \pm 0.0$ & $51.1 \pm 2.7$ \\
Fibroblasts & $4.7 \pm 0.8$ & $0.7 \pm 0.1$ & $9.3 \pm 3.3$ & $13.3 \pm 4.8$ & $1.5 \pm 0.5$ \\
SK-BR-1-III & $5.2 \pm 1.3$ & $13.2 \pm 0.7$ & $43.8 \pm 3.6$ & $0.0 \pm 0.0$ & $45.6 \pm 2.8$ \\
HSB & $6.0 \pm 0.8$ & $0.6 \pm 0.4$ & $4.3 \pm 1.7$ & $11.8 \pm 7.7$ & $13.8 \pm 4.8$ \\
Lymphocytes & $9.3 \pm 0.9$ & $7.7 \pm 2.8$ & $16.8 \pm 0.4$ & $23.7 \pm 4.6$ & $248 \pm 78$ \\
B0467 & $9.4 \pm 1.3$ & $1.3 \pm 0.3$ & $18.3 \pm 4.5$ & $65.0 \pm 7.6$ & $18.9 \pm 2.6$ \\
SK-OV-3 & $19.4 \pm 0.9$ & $1.6 \pm 0.3$ & $34.4 \pm 12.9$ & $4.5 \pm 1.1$ & $1.7 \pm 0.9$ \\
CAMA-I & $19.7 \pm 1.6$ & $1.1 \pm 0.1$ & $21.8 \pm 4.6$ & $15.9 \pm 2.3$ & $5.5 \pm 1.8$ \\
\hline
\end{tabular}

Levels of various antioxidants were measured in $0.2 \%$ Triton X-100 lysates of cells at a concentration of $10-20 \times 10^{6}$ cells $/ \mathrm{ml}$. Values represent the means of triplicates of 2-3 experiments \pm SEM. Catalase is expressed in Baudhuin units per milligram protein $\times 10^{3}$, GSH as nanomoles per milligram protein, GPO and GR as nanomoles of NADPH oxidized per minute per milligram protein. $\mathrm{LD}_{50} \mathrm{~S}$ are calculated as described in the legend of Table $\mathrm{I}$. * This value represents $\mathrm{LD}_{30}\left(\mathrm{mM} \mathrm{H}_{2} \mathrm{O}_{2}\right)$.

HSB were not substantially sensitized by any of the inhibitors tested. The combination of azide and BSO was no more effective than the more effective agent alone. In apparently utilizing the GSH redox cycle for defense against $\mathrm{H}_{2} \mathrm{O}_{2}$, fibroblasts resembled murine cells $(2,3)$, although the $\mathrm{LD}_{50}$ of $\mathrm{H}_{2} \mathrm{O}_{2}$ for fibroblasts $(4.7 \mathrm{mM})$ was approximately two orders of magnitude higher than that of the murine cells. Thus, the level of sensitivity or resistance to $\mathrm{H}_{2} \mathrm{O}_{2}$ exhibited by a cell does not appear to predict whether it relies on the GSH redox cycle to resist injury by $\mathrm{H}_{2} \mathrm{O}_{2}$.

Identification of $\mathrm{H}_{2} \mathrm{O}_{2}$-consuming pathways. Although it was assumed that degradation of $\mathrm{H}_{2} \mathrm{O}_{2}$ was the primary defense of cells against it, the possibility was considered that different pathways might be involved in resistance to and degradation of $\mathrm{H}_{2} \mathrm{O}_{2}$. The rate of $\mathrm{H}_{2} \mathrm{O}_{2}$ consumption with or without prior exposure to BSO (to deplete GSH) and azide (to inhibit catalase) was therefore measured in five cell types. The results for four of them are displayed in Fig. 2. $17 \mathrm{~h}$ pretreatment with BSO had no effect on the cells' capacity to consume 5 mM $\mathrm{H}_{2} \mathrm{O}_{2}$ over a $3 \mathrm{~h}$ period. In contrast, azide inhibited $\mathrm{H}_{2} \mathrm{O}_{2}$ consumption by an average of $90 \%$. Results with BSO plus azide were the same as with azide alone. Similar results were seen with $\mathrm{B} 0467$, a cell line whose $\mathrm{LD}_{50}$ for $\mathrm{H}_{2} \mathrm{O}_{2}$ was unaffected by azide (Table III). Thus, all five cell types tested appeared to utilize an azide-sensitive mechanism (probably catalase) almost exclusively to catabolize millimolar concentrations of extracellular $\mathrm{H}_{2} \mathrm{O}_{2}$.

\section{Discussion}

We conclude from this study that all nine human cell types tested were markedly resistant to lysis by $\mathrm{H}_{2} \mathrm{O}_{2}$ (with $\mathrm{LD}_{50} \mathrm{~S}$ in the 2-20 $\mathrm{mM}$ range), that under appropriate experimental conditions, resistance to $\mathrm{H}_{2} \mathrm{O}_{2}$ could be manifest in the absence

Table III. Effect of Inhibitors of Antioxidant Defenses on Human Cell Lysis by $\mathrm{H}_{2} \mathrm{O}_{2}$

\begin{tabular}{|c|c|c|c|c|c|c|}
\hline \multirow[b]{2}{*}{ Cell type } & \multirow[b]{2}{*}{ Control $\mathrm{LD}_{\mathbf{s}}$} & \multicolumn{5}{|c|}{ Percent of control } \\
\hline & & BSO & BCNU & AT & Azide & Azide/BSO \\
\hline & $m M$ & & & & & \\
\hline Erythrocytes & $1.7 \pm 0.1^{*}$ & $\ddagger$ & $122 \pm 28$ & $29 \pm 15$ & $29 \pm 1$ & $\ddagger$ \\
\hline SK-BR-2-III & $3.3 \pm 0.7$ & $67 \pm 4$ & $70 \pm 9$ & $86 \pm 8$ & $48 \pm 6$ & $70 \pm 24$ \\
\hline Fibroblasts & $4.7 \pm 0.8$ & $5 \pm 1$ & $10 \pm 6$ & $68 \pm 26$ & $44 \pm 9$ & $4 \pm 2$ \\
\hline SK-BR-1-III & $5.2 \pm 1.3$ & $121 \pm 21$ & $36 \pm 4$ & $54 \pm 18$ & $44 \pm 11$ & $78 \pm 21$ \\
\hline HSB & $6.0 \pm 0.8$ & $87 \pm 14$ & $112 \pm 52$ & $80 \pm 10$ & $72 \pm 11$ & $54 \pm 4$ \\
\hline Lymphocytes & $9.3 \pm 0.3$ & $137 \pm 36$ & $125 \pm 19$ & $93 \pm 15$ & $23 \pm 3$ & $37 \pm 17$ \\
\hline B0467 & $9.4 \pm 1.3$ & $140 \pm 20$ & $74 \pm 25$ & $63 \pm 14$ & $77 \pm 13$ & $85 \pm 14$ \\
\hline SK-OV-3 & $19.4 \pm 0.9$ & $74 \pm 16$ & $66 \pm 27$ & $26 \pm 10$ & $24 \pm 10$ & $23 \pm 13$ \\
\hline CAMA-I & $19.7 \pm 1.6$ & $99 \pm 4$ & $98 \pm 12$ & $60 \pm 16$ & $43 \pm 2$ & $49 \pm 7$ \\
\hline
\end{tabular}

$2 \times 10^{5}{ }^{51} \mathrm{Cr}$-labeled cells per $\mathrm{ml}$ in $\mathrm{M}-5 \% \mathrm{HS}$ were incubated in the presence of reagent $\mathrm{H}_{2} \mathrm{O}_{2}(0.03-30 \mathrm{mM})$ for $3 \mathrm{~h}$ at $37^{\circ} \mathrm{C}$ in $5 \% \mathrm{CO}_{2} / 95 \%$ air. Specific ${ }^{51} \mathrm{Cr}$ release was measured and $\mathrm{LD}_{50}$ levels were calculated by interpolation. Before the assay, cells were treated with vehicle alone or where indicated, with $100 \mu \mathrm{g} / \mathrm{ml} \mathrm{BCNU}$ for $10 \mathrm{~min}, 50 \mathrm{mM}$ aminotriazole for $60 \mathrm{~min}$ in the presence of $0.44 \mathrm{U}$ of glucose oxidase for the last $30 \mathrm{~min}, 0.2 \mathrm{mM}$ BSO for $17 \mathrm{~h}$. When used, AT and BSO also were present throughout the assay. Where indicated, $0.5 \mathrm{mM}$ azide was present during the assay period only. Values represent the mean \pm SEM of triplicates in $2-10$ experiments. * This value represents $\mathrm{LD}_{30}\left(\mathrm{mM} \mathrm{H}_{2} \mathrm{O}_{2}\right)$. ¥ Indicates not tested. 

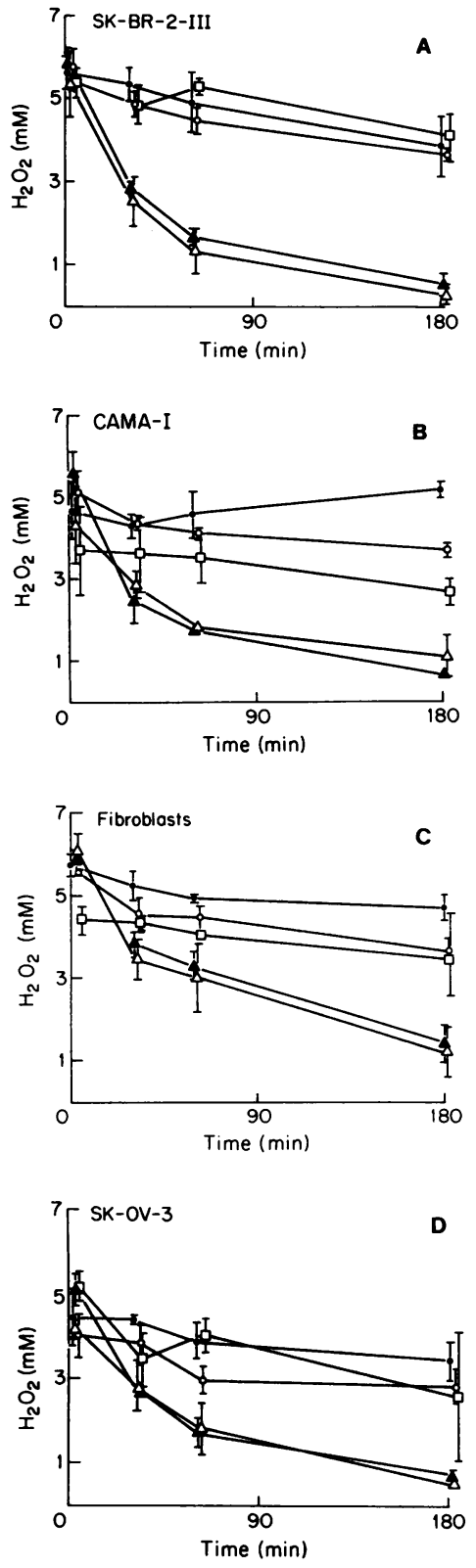

Figure 2. $\mathrm{H}_{2} \mathrm{O}_{2}$ consumption by human cells. 5 $\times 10^{5}$ cells plated on 13 mm coverslips or $1 \times 10^{6}$ cells in $1 \mathrm{ml}$ of M-5\% HS were incubated with $\sim 5$ $\mathrm{mM} \mathrm{H}_{2} \mathrm{O}_{2}$ at $37^{\circ} \mathrm{C}$ in $5 \%$ $\mathrm{CO}_{2} / 95 \%$ air. At $0,30,60$, and $180 \mathrm{~min}, \mathrm{H}_{2} \mathrm{O}_{2}$ remaining in the medium was measured using an oxygen electrode. Cells treated with BSO were preincubated with $0.2 \mathrm{mM}$ drug for $17 \mathrm{~h}$ before assay and then throughout the assay. Azide at $0.5 \mathrm{mM}$ was present during the 180-min exposure of the cells to $\mathrm{H}_{2} \mathrm{O}_{2}$. Points are means \pm SEM of three to six experiments. $(\bullet)$, no cell control; ( $\Delta)$, cells $+\mathrm{H}_{2} \mathrm{O}_{2} ;(\Delta)$, BSOtreated cells $+\mathrm{H}_{2} \mathrm{O}_{2} ;(\mathrm{O})$, azide treated cells $+\mathrm{H}_{2} \mathrm{O}_{2}$; (ㅁ), $\mathrm{BSO}+$ azide treated cells $+\mathrm{H}_{2} \mathrm{O}_{2}$.

of its detectable consumption, and that the specific activity or content of the primary known $\mathrm{H}_{2} \mathrm{O}_{2}$ scavenging systems (catalase and the GSH redox cycle) did not predict which of them, if either, played a major role in resistance to $\mathrm{H}_{2} \mathrm{O}_{2}$-mediated cytolysis in a given cell. These findings have implications for pathophysiologic and therapeutic concepts involving oxidative cellular injury and its pharmacologic control.

We focused on resistance to and degradation of $\mathrm{H}_{2} \mathrm{O}_{2}$ because preliminary studies identified $\mathrm{H}_{2} \mathrm{O}_{2}$ as the only enzymatically degradable $\mathrm{O}_{2}$ reduction product capable of rapidly lysing the cells under study. The toxicity of $\mathrm{H}_{2} \mathrm{O}_{2}$ rather than $\mathrm{O}_{2}^{-}$under these conditions agrees with prior studies on fibroblasts (26) and lymphocytes (27). Thus, our attention was directed away from measurement of tumor cell superoxide dismutase (28-34) and toward study of catalase and GSH redox cycle components and the consequences of their pharmacologic inhibition or depletion. However, it is possible that

$\mathrm{H}_{2} \mathrm{O}_{2}$ lyses cells through interaction with components of the assay system, such as $\mathrm{O}_{2}^{-}$or $\mathrm{Fe}^{++}$(35) of cellular origin, resulting in the formation of $\mathrm{OH}^{*}$ or uncharacterized toxins in the vicinity of critical intracellular targets.

Measurement of the rate at which intact cells degrade $\mathrm{H}_{2} \mathrm{O}_{2}$ has apparently been reported for only one murine tumor (19), as well as for lymphocytes (27), granulocytes (36), and platelets (36). Our present study revealed that human cell degradation of $\mathrm{H}_{2} \mathrm{O}_{2}$ was rapid (mean initial rate, $84 \mathrm{nmol} \mathrm{H}_{2} \mathrm{O}_{2} / \mathrm{min}$ per $\mathrm{mg}$ cell protein with initial $\left[\mathrm{H}_{2} \mathrm{O}_{2}\right]=5 \mathrm{mM}$ ) and almost completely inhibitable by $0.5 \mathrm{mM} \mathrm{NaN}$, presumably reflecting the predominant role of catalase under these conditions. Yet, the rate of azide-inhibitable $\mathrm{H}_{2} \mathrm{O}_{2}$ consumption by a given cell type was not correlated with the specific activity of its catalase as measured in $0.2 \%$ Triton $\mathrm{X}-100$ cell lysates (correlation coefficient, -0.71 ). This emphasizes that assays of enzymes in lysates may not closely predict their function in intact cells. The unlikely possibility exists that an azide-sensitive enzyme other than catalase was responsible for most of the $\mathrm{H}_{2} \mathrm{O}_{2}$ consumption.

More important, virtually complete inhibition of detectable $\mathrm{H}_{2} \mathrm{O}_{2}$ consumption did not sensitize the cells to destruction by all but millimolar quantities of $\mathrm{H}_{2} \mathrm{O}_{2}$. This demonstrates that resistance to the toxicity of $\mathrm{H}_{2} \mathrm{O}_{2}$ can have a biochemical basis distinct from catabolic pathways that perceptibly lower the extracellular concentration of $\mathrm{H}_{2} \mathrm{O}_{2}$. It is therefore clear that the cell types studied exhibited an inherent resistance to lysis by $\mathrm{H}_{2} \mathrm{O}_{2}$ even when their ability to consume $\mathrm{H}_{2} \mathrm{O}_{2}$ was impaired. In theory, the GSH redox cycle could function either to degrade $\mathrm{H}_{2} \mathrm{O}_{2}$ or to reduce lipid peroxides. The latter action would repair cellular injury rather than prevent it, and might be manifest as a resistance to peroxidative lysis out of proportion to consumption of peroxide. However, as noted below, a prominent role for the GSH redox cycle in resistance to $\mathrm{H}_{2} \mathrm{O}_{2}$-mediated cytolysis was shown in only one of the nine cell types studied.

In contrast to the predominance of an azide-sensitive mechanism (probably catalase) in degradation of millimolar $\mathrm{H}_{2} \mathrm{O}_{2}$ in all the human cell types tested, resistance of the cells to lysis by millimolar $\mathrm{H}_{2} \mathrm{O}_{2}$ during $3 \mathrm{~h}$ of exposure was attributable in part to the GSH redox cycle in two cell lines, catalase in seven cell lines, and neither in two others. These interpretations are based on the degree to which the cells were sensitized to $\mathrm{H}_{2} \mathrm{O}_{2}$ by pharmacologic agents directed against GSH, GR, or catalase. These patterns could not be predicted either from the $\mathrm{LD}_{50}$ of $\mathrm{H}_{2} \mathrm{O}_{2}$ for a given cell type nor from the specific activity or content of the enzymes and substrates involved. These results are consistent with those of Marklund et al. (30), who found no correlation between sensitivity to ionizing radiation or oxygen radical-producing drugs and levels of catalase, GPO, or superoxide dismutase in 46 normal and neoplastic cell types.

We do not understand the biochemical basis for resistance to millimolar $\mathrm{H}_{2} \mathrm{O}_{2}$ on the part of the human cell types studied here. We have not yet measured certain nonenzymatic antioxidants, such as ascorbate and tocopherol (37). It seems critical to identify the molecular targets whose oxidation by $\mathrm{H}_{2} \mathrm{O}_{2}$ leads to rapid cell death, and to measure the pool sizes and rates of regeneration of these molecules at rest and during oxidative stress. Another unknown is the role of the subcellular localization of antioxidant defense systems in relation to the critical targets of oxidative injury. Finally, the ${ }^{51} \mathrm{Cr}$-release 
assay used in this study reflects cell lysis. It is possible that $\mathrm{H}_{2} \mathrm{O}_{2}$ causes important but nonlytic forms of cellular damage at lower concentrations, as previously reported for platelets (36), PMNs (38), lymphocytes (39), natural killer cells (40), and endothelial cells (41).

In the mouse, we have found that 22 cell types are lysed within 3-4 h of exposure to $\mathrm{H}_{2} \mathrm{O}_{2}$ in the range of $3.73 \times 10^{-5}$ $\mathrm{M}\left(2.98-4.66 \times 10^{-5} \mathrm{M}\right)$ (geometric mean, $\mathrm{LD}_{50} \pm \mathrm{SEM}$ ) (Fig. $3)$. For many of the murine tumors, lytic concentrations of $\mathrm{H}_{2} \mathrm{O}_{2}$ could be achieved rapidly by phagocytic leukocytes in a 1.4- to 4.5-fold excess over tumor cells, resulting in tumor cell death in vitro (9). Solid-phase glucose oxidase could inactivate some of these same tumors in vivo by generating $\mathrm{H}_{2} \mathrm{O}_{2}$ in the tumor bed, without harming the host (42). In contrast, the human cells studied here have $\mathrm{LD}_{50}$ s approximately 100 times higher (geometric mean $\pm \mathrm{SEM}=3.55 \times 10^{-3} \mathrm{M}, 1.92-6.57$ $\times 10^{-3} \mathrm{M}$ ) (Fig. 3) with only one fibroblast line (FS4) exhibiting an $\mathbf{L D}_{s 0}$ in the same range as murine cells. Recently the amount of $\mathrm{H}_{2} \mathrm{O}_{2}$ generated by activated neutrophils has been quantified (43) and found to peak at $12.2 \mu \mathrm{M}$ for $3 \times 10^{5}$ cells $/ \mathrm{ml}$. We think it unlikely that direct, lytic oxidative injury will be sustained by most of these human tumors under attack by leukocytes or enzymatic $\mathrm{H}_{2} \mathrm{O}_{2}$-generating systems. However, in this report we have only studied nine types of human cells, seven of them after in vitro passage, and do not know to what extent these observations may apply to other human cell types or to tumor masses in vivo. Several hematopoietic human tumor lines (CEM [44], Raji [45], and K562 [46]) have been reported to be susceptible to lysis by leukocyte-derived oxidants in other studies. In addition, an $\mathrm{LD}_{50}$ of $1.4 \mathrm{mM} \mathrm{H}_{2} \mathrm{O}_{2}$ has been reported for a murine sarcoma (47). Thus, the general distinction drawn here between large numbers of unselected murine and human cell types does not reflect an absolute species difference.

Indeed, it is of interest that certain normal human cell types seem to be much more sensitive to oxidative injury than the cells studied here. Weiss et al. (48) showed that human umbilical vein endothelial cells were sensitive to lysis by $\mathrm{H}_{2} \mathrm{O}_{2}$ released from stimulated neutrophils. The concentration of $\mathrm{H}_{2} \mathrm{O}_{2}$ generated by the neutrophils was $67 \mu \mathrm{M}, 1-2$ logs lower

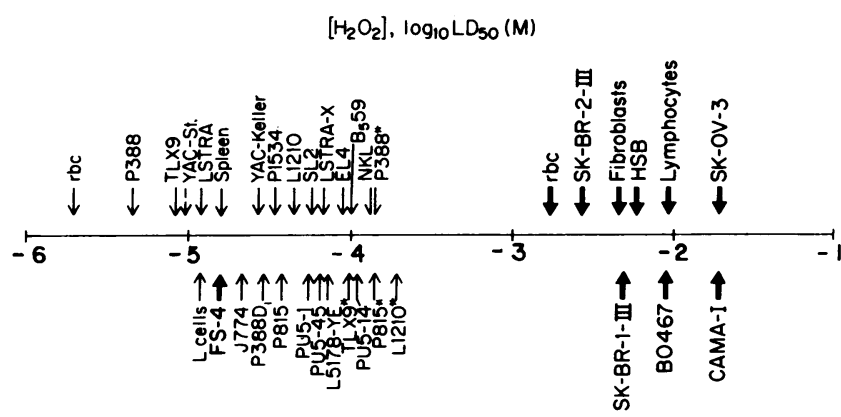

Figure 3. $\left[\mathrm{H}_{2} \mathrm{O}_{2}\right], \log _{10} \mathrm{LD}_{50}(\mathrm{M})$. Values indicated are $\log _{10}$ of molar $\mathrm{LD}_{50}$ 's of $\mathrm{H}_{2} \mathrm{O}_{2}$ averaged for 105 experiments with 22 types of murine cells $(\rightarrow)$ and 10 types of human cells $(\rightarrow)$. Results for FS-4 (a human fibroblast line) and 36 experiments with murine cells are from earlier reports $(9,51,52)$ and have been averaged with results of 32 subsequent unpublished experiments. 18 additional experiments with murine cells were performed during the studies with human cells described in this report; these are presented separately and denoted (*). rbc, erythrocytes. than the $\mathrm{LD}_{50} \mathrm{~s}$ of the human cells in this study. Harlan et al. (49) documented that micromolar $\mathrm{H}_{2} \mathrm{O}_{2}$ could lyse human endothelial cells and that the GSH redox cycle could protect these cells from a flux of $\mathrm{H}_{2} \mathrm{O}_{2}$ generated by glucose oxidase and glucose (50). Simon et al. (26) lysed human fibroblasts with enzymatically generated fluxes of $\mathrm{H}_{2} \mathrm{O}_{2}$ of 1.6-1.9 $\mu \mathrm{M}$ / min (26). Even in our study, where human fibroblasts were insensitive to fluxes of $\mathrm{H}_{2} \mathrm{O}_{2}$ attainable with glucose oxidase or xanthine oxidase, the cells were rendered up to 20 -fold more sensitive to $\mathrm{H}_{2} \mathrm{O}_{2}$ by inhibition of the $\mathrm{GSH}$ redox cycle with BSO or BCNU. Thus, the possibility remains that endothelial cells or other components of tumor vasculature might be suitable targets for the localized delivery of oxidant stress to the tumor bed, in conjunction with pharmacologic inhibition of the GSH redox cycle $(3,4)$.

\section{Acknowledgments}

We thank Dr. Zanvil Cohn for helpful discussions and review of the manuscript, and Ms. Judy Adams for aid in preparation of the figures. This work was supported by grant PO30198 from the National Cancer Institute. Dr. O'Donnell-Tormey is a recipient of the Cancer Research Institute/James T. Lee Foundation Fellowship.

\section{References}

1. Nathan, C. F. 1982. Secretion of oxygen intermediates: role in effector functions of activated macrophages. Fed. Proc. 41:2206-2211.

2. Nathan, C. F., B. A. Arrick, H. W. Murray, N. M. DeSantis, and Z. A. Cohn. 1981. Tumor cell anti-oxidant defenses. Inhibition of the glutathione redox cycle enhances macrophage-mediated cytolysis. J. Exp. Med. 153:766-782.

3. Arrick, B. A., C. F. Nathan, O. W. Griffith, and Z. A. Cohn. 1982. Glutathione depletion sensitizes tumor cells to oxidative cytolysis. J. Biol. Chem. 257:1231-1237.

4. Arrick, B. A., C. F. Nathan, and Z. A. Cohn. 1983. Inhibition of glutathione synthesis augments lysis of murine tumor cells by sulfhydryl-reactive antineoplastics. J. Clin. Invest. 71:258-267.

5. Fogh, J., W. C. Wright, and J. D. Loveless. 1977. Absence of HeLa cell contamination in 169 cell lines derived from human tumors. J. Natl. Canc. Inst. 58:209-214.

6. Fogh, J., J. M. Fogh, and T. Orefeo. 1977. One hundred and twenty-seven cultured human tumor cell lines producing tumors in nude mice. J. Natl. Cancer Inst. 59:221-226.

7. Fogh, J., and G. Trempe. 1975. New human tumor cell lines. In Human Tumor Cells In Vitro. J. Fogh, editor. Plenum Press, New York. 115-159.

8. Nakagawara, A., C. F. Nathan, and Z. A. Cohn. 1981. Hydrogen peroxide metabolism in human monocytes during differentiation in vitro. J. Clin. Invest. 68:1243-1252.

9. Nathan, C. F., L. H. Brukner, S. C. Silverstein, and Z. A. Cohn. 1979. Extracellular cytolysis by activated macrophages and granulocytes. I. Pharmacologic triggering of effector cells and the release of hydrogen peroxide. J. Exp. Med. 149:84-99.

10. Tietze, F. 1969. Enzymic method for quantitative determination of nanogram amounts of total and oxidized glutathione: applications to mammalian blood and other tissues. Anal. Biochem. 27:502-522.

11. Roos, D., R. S. Weening, A. A. Voetman, M. L. J. van Schaik, A. A. M. Bot, L. J. Meerhof, and J. A. Loos. 1976. Protection of phagocytic leukocytes by endogenous glutathione: studies in a family with glutathione reductase deficiency. Blood. 53:851-866.

12. Paglia, D. E., and W. N. Valentine. 1967. Studies on the quantitative and qualitative characterization of erythrocyte glutathione peroxidase. J. Lab. Clin. Med. 70:158-169.

13. Baudhuin, P., H. Beaufay, Y. Rahman-Li, O. Z. Sellinger, R. 
Wattiaux, P. Jacques, and C. deDuve. 1964. Tissue fractionation studies, 17. Intracellular distribution of monoamine oxidase, aspartate aminotransferase, alanine aminotransferase, D-amino acid oxidase and catalase in rat liver tissue. Biochem. J. 92:179-184.

14. Maehly, A. C., and B. Chance. 1954. The assay of catalase and peroxidases. In Methods of Biochemical Analysis, Vol. I. D. Glick, editor. Interscience Publishers, Inc., New York. 357-418.

15. Avigad, G. 1978. An NADH coupled assay system for galactose oxidase. Anal. Biochem. 86:470-476.

16. Shigeoka, S., N. Yoshihisa, and S. Kitaoka. 1980. Purification and some properties of L-ascorbic acid-specific peroxidase in Euglena gracilis z. Arch. Biochem. Biophys. 201:121-127.

17. Lowry, O. H., H. J. Rosebrough, A. L. Farr, and R. J. Randall. 1951. Protein measurement with the Folin phenol reagent. J. Biol. Chem. 193:265-275.

18. Klein, S. M., G. Cohen, and A. I. Cederbaum. 1980. The interaction of hydroxyl radicals with dimethylsulfoxide produces formaldehyde. FEBS Lett. 116:220-222.

19. Schroy, C. B., and J. E. Biaglow. 1981. Use of an oxidase electrode to determine factors affecting the in vitro production of hydrogen peroxide by Ehrlich cells and 1-chloro-2,4-dinitrobenzene. Biochem. Pharmacol. 30:3201-3207.

20. McCord, J. M., and I. Fridovich. 1968. The reduction of cytochrome C by milk xanthine oxidase. J. Biol. Chem. 243:57535760.

21. Klebanoff, S. J. 1967. Iodination of bacteria: a bactericidal mechanism. J. Exp. Med. 126:1063-1078.

22. Edelson, P. J., and Z. A. Cohn. 1973. Peroxidase-mediated mammalian cell cytotoxicity. J. Exp. Med. 138:318-323.

23. Greenstein, J. P. 1947. Biochemistry of Cancer. Academic Press Inc., New York. 1-389.

24. Bozzi, A., I. Mavelli, B. Mondovi, R. Strom, and G. Rotilio. 1979. Differential sensitivity of tumor cells to externally generated hydrogen peroxide. Role of glutathione and related enzymes. Cancer Biochem. Biophys. 3:135-141.

25. Margoliash, E., and A. Novogrodsky. 1958. A study of the inhibition of catalase by 3-amino-1:2:4 triazole. Biochem. J. 68:468475.

26. Simon, R. H., C. H. Scoggin, and D. Patterson. 1981. Hydrogen peroxide causes the fatal injury to human fibroblasts exposed to oxygen radicals. J. Biol. Chem. 256:7181-7186.

27. Farber, C. M., L. F. Liebes, D. N. Kanganis, and R. Silber. 1984. Human B lymphocytes show greater susceptibility to $\mathrm{H}_{2} \mathrm{O}_{2}$ toxicity than T lymphocytes. J. Immunol. 132:2543-2546.

28. Bozzi, A., I. Mavelli, A. Finazzi Agro, R. Strom, A. M. Wolf, B. Mondovi, and G. Rotilio. 1976. Enzyme defense against reactive oxygen derivatives. II. Erythrocytes and tumor cells. Mol. Cell. Biochem. 10:11-16.

29. Lankin, U. Z., and S. M. Gurevich. 1976. Inhibition of the peroxidation of lipids and detoxification of lipoperoxides by protective enzymes (superoxide dismutase, glutathione peroxidase, and glutathione reductase) in experimental malignant growth. Dokl. Acad. Nauk. SSSR. 226:705-708.

30. Marklund, S. L., N. G. Wếstman, E. Lundgren, and G. Roos. 1982. Copper- and zinc-containing superoxide dismutase, manganesecontaining superoxide dismutase, catalase, and glutathione peroxidase in normal and neoplastic human cell lines and normal human tissues. Cancer Res. 42:1955-1961.

31. Oberley, L. W., I. B. Bize, S. K. Sahu, S. W. H. C. Leuthauser, and H. E. Gruber. 1978. Superoxide dismutase activity of normal murine liver, regenerating liver; and $\mathrm{H} 6$ hepatoma. J. Natl. Cancer Inst. 61:375-379.

32. Oberley, L. W., and G. R. Buettner. 1979. Role of superoxide dismutase in cancer: a review. Cancer Res. 39:1141-1149.
33. Petkau, A., L. G. Monasterski, K. Kelly, and H. G. Friesen. 1977. Modification of superoxide dismutase in rat mammary carcinoma. Res. Commun. Chem. Pathol. Pharmacol. 17:125-132.

34. Yamanaka, N. Y., and D. Deamer. 1974. Superoxide dismutase activity in WI-38 cell cultures: effects of age, trypsinization and SV-40 transformation. Physiol. Chem. Phys. 6:94-106.

35. Repine, J. E., R. B. Fox, and E. M. Berger. 1981. Hydrogen peroxide kills Staphylococcus aureus by reacting with staphylococcal iron to form hydroxyl radical. J. Biol. Chem. 256:7094-7096.

36. Levine, P. H., R. S. Weinger, J. Simon, K. L. Scoon, and N. I. Krinsky. 1976. Leukocyte-platelet interaction. Release of hydrogen peroxide by granulocytes as a modulator of platelet reactions. J. Clin. Invest. 57:955-963.

37. Dodge, J. T., G. Cohen, H. J. Kayden, and G. B. Phillips. 1967. Peroxidative hemolysis of red blood cells from patients with abetalipoproteinemia (acanthocytosis). J. Clin. Invest. 46:357-358.

38. Baehner, R. L., L. A. Boxer, J. M. Allen, and J. Davis. 1977. Autooxidation as a basis for altered function by polymorphonuclear leukocytes. Blood. 50:327-335.

39. Kraut, E. H., and A. L. Sagone. 1981. The effect of oxidant injury on the lymphocyte membrane and functions. J. Lab. Clin. Med. 98:697-703.

40. Seaman, W. E., T. D. Gindhart, M. A. Blackman, D. Dalal, N. Talal, and Z. Werb. 1982. Suppression of natural killing in vitro by monocytes and polymorphonuclear leukocytes. J. Clin. Invest. 69:876888 .

41. Ager, A., and J. L. Gordon. 1984. Differential effects of hydrogen peroxide on indices of endothelial cell function. J. Exp. Med. 159:592-603.

42. Nathan, C. F., and Z. A. Cohn. 1981. Antitumor effects of hydrogen peroxide in vivo. J. Exp. Med. 154:1539-1553.

43. Test, S. T., and S. J. Weiss. 1984. Quantitative and temporal characterization of the extracellular $\mathrm{H}_{2} \mathrm{O}_{2}$ pool generated by human neutrophils. J. Biol. Chem. 259:399-405.

44. Weiss, S. J., and A. Slivka. 1982. Monocyte and granulocytemediated tumor cell destruction. A role for the hydrogen peroxidemyeloperoxidase-chloride system. J. Clin. Invest. 69:255-262.

45. Dallegri, F., G. Frumento, and F. Patrone. 1983. Mechanisms of tumor cell destruction by PMA-activated human neutrophils. Immunology. 48:273-279.

46. Mavier, P., and T. S. Edgington. 1984. Human monocytemediated tumor cytotoxicity. I. Demonstration of an oxygen-dependent myeloperoxidase-independent mechanism. J. Immunol. 132:1980-1986.

47. Adams, D. O., W. J. Johnson, E. Fiorito, and C. F. Nathan. 1981. Hydrogen peroxide and cytolytic factor can interact synergistically in effecting cytolysis of neoplastic targets. J. Immunol. 127:1973-1977.

48. Weiss, S. J., J. Young, A. F. LoBuglio, A. Slivka, and N. F. Nimeh. 1981. Role of hydrogen peroxide in neutrophil-mediated destruction of cultured endothelial cells. J. Clin. Invest. 68:714-721.

49. Harlan, J. M., P. D. Killen, L. A. Harker, G. E. Striker, and D. G. Wright. 1981. Neutrophil-mediated endothelial injury in vitro. J. Clin. Invest. 68:1394-1403.

50. Harlan, J. M., J. D. Levine, K. S. Callahan, B. R. Schwartz, and L. A. Harker. 1984. Glutathione redox cycle protects cultured endothelial cells against lysis by extracellularly generated hydrogen peroxide. J. Clin. Invest. 73:706-713.

51. Nathan, C. F. 1979. The role of oxidative metabolism in the cytotoxicity of activated macrophages after pharmacologic triggering. In Immunobiology and Immunotherapy of Cancer, W. D. Terry and Y. Yamamura, editors. Elsevier/North-Holland, New York. 59-70.

52. Freedman, V. H., T. E. Gorrell, C. F. Nathan, C. S. Copeland, and S. C. Silverstein. 1984. Bacillus Calmette-Guerin-activated murine macrophages kill syngeneic melanoma cells under strict anaerobic conditions. J. Exp. Med. 160:94-107. 